\title{
Derivation of the Monetary Base
}

\author{
ANATOL B. BALBACH AND ALBEPT E. BURGER
}

LTHOUGM the monetary base has been a key concept in monetary analysis for two decades, its use has been primarily restricted to the monetary systems of industrial nations. ${ }^{1}$ Specifically, the base as conn structed and measured in the United States has tended to be applied with some modifications to other economies. This article is an attempt to establish a general definition of a monetary base applicable to all relevant institutional structures and to provide guidelines for the identification and measurement of the base.

Given a set of institutional arrangements and predictable behavior on the part of market participants, changes in the monetary base produce predictable changes in the money stock. Under these conditions the base can be used as a predictor of the money stock and as a variable whose control implies the control of changes in the quantity of money. Thus the practical use of the base encompasses only those institutional structures where the money stock cannot be predicted and controlled directly by monetary authorities, bat where the base can be measured and affected.

Where it is the case that every unit of the money stock can be directly created or destroyed by monetary authorities, or that economic forces or policy actions affect the base and the money stock by exactly

1For further discussion of the concepts of monetary base and high-powered money, see Karl Brmmer and Allan $\mathrm{H}$. Meltzer, "An Alternative Approach to the Monetary Mechanism," U.S., Congress, Honse of Representatives, Committee on Banking and Currency, Subcommittee on Domestic Finance, $88 \mathrm{th}$ Cong., 2nd sess., 17 Augast 1964, pp. 9-20; Milton Friedman and Anna Jacobson Schwart, A Monetary History of the United States 1867-1960 (Princeton: Princeton Universily Press, 1963); Phillip Cagan, Determinants and Effects of Changes it the Stock of Money 1875-1960) (New York: National Bureau of Economic Wesearch, 1965). Also see Lemall C. Andersen and Jerry L. Jordan "The Monetary Base - Explanation and Analytical Use" this Review (August 1968), pp. $7-J 1$. the same magnitudes, there is no reason to resort to the use of the base concept. Alternatively, if the constraint on money creation consists solely of a single money-creator's decisions as to how much money to create in order to have it acceptable as money to all users, the base, while it exists in principle, is not objectively measurable and cannot be used either as a predictor or as a control variable. This leaves the monetary base as a useful concept in monetary systems which are characterized by the existence of fiat money, more than one money creating institution, and fractional reserve banking.

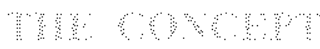

In a system which exhibits these features, the money stock in the hands of the public will potentially consist of commodity money (such as gold and silver coins), liabilities of monetary authorities (currency) and liabilities of private institutions (bank notes and/ or bank deposits). These assets of the nonbanking public will be used as money only if transactions costs associated with other assets are higher. In other words, since the productivity of any asset used as money lies in its ability to facilitate transactions, it must be an instrument which minimizes the costs of conducting transactions. Apart from such features as divisibility, convenience and safety it must also reasonably maintain its purchasing power vis-a-vis other assets. Any asset that is convenient in every respect but whose purchasing power fluctuates widely and unpredictably will impose high risks on its holders and, in effect, high transaction costs.

The stability of purchasing power, as used here, refers to its exchange value against the bundle of all other available assets, goods, and services. One of the main requisites of this stability is a relatively stable supply of this asset called money. If money is cre- 
ated without restraint or if its production fluctuates widely, its purchasing power will fluctuate accordingly, and the costs imposed on its holders will encourage them to use some other asset to facilitate transactions. Thus, for any asset to function as money, its users must be convinced that its supply is constrained either by some institution they trust or by some set of other assets that are deemed to be relatively fixed in quantity or adequately controlled by market or institutional forces. The monetary base is this set of assets that constrains the growth of the money stock.

Commodity money is accepted because of the belief that market forces are such as to assure a relatively stable supply. Government liabilities - currency - are accepted so long as it is believed that the monetary authorities will maintain a relatively stable growth of these liabilities. But what induces the nonbanking public to accept liabilities of private, profit-making institutions such as banks? Obviously, it is because something limits the growth of these deposits and hence insures that there will remain a fairly stable rate of exchange of these deposits for other assets.

In a banking system where there exists more than one bank and where the money stock is comprised solely of bank liabilities (deposits, currency, and coin issued by the banks), the users of these liabilities will frequently deposit liabilities of one bank at another bank. If the banks were to use assets which were eacl others' liabilities as a basis for issuing new money, there would be no effective constraint on the expansion of money and, consequently, banks conld find that their liabilities cease to be accepted as money. Knowing this, they will not accept each others' liabilities without being able to convert them into some asset which is not dominated by actions of banks themselves. The asset that will emerge will also have the lowest transactions costs of all assets acceptable for interbank transactions. This asset, whatever it is, will then constitute part of the monetary base.

Each bank, knowing that its liabilities will be presented to it by other banks for conversion into this acceptable asset, will have to hold a stock of this asset as a reserve for conversion. In the absence of legal constraints, the size of this cushion or reserve, relative to the amount of monetary liabilities it creates, will depend upon the probability with which the bank's monetary liabilities are deposited at other banks. Thus, the total amount of this reserve asset will constrain the amount of money that can be prow duced by the system.
If the money stock includes commodity money or currency issued by monetary authorities in addition to private bank liabilities, then the banks will have to be ready to convert their monetary liabilities into forms acceptable not only to other banks but also to the nonbanking public. Thus they will have to hold a reserve of those assets that may be demanded by both. The monetary base will then consist not only of those assets that banks use to settle monetary liabilities among themselves but also those assets that are used to satisfy the conversion demands of the public. This does not preclude the possibility that the interbank settlement asset is the same as the one that is used in settling with the public.

To sum up, in a system where the money stock consists of commodity money, governmental liabili.. ties, and bank liabilities, the base will consist of commodity money, governmental monetary liabilities, and whatever assets the banks use to settle interbank debts. The assets that constrain the growth of money stock (the monetary base) can therefore be identified in any monetary system by ascertaining and summing the following:

1. those assets which the consolidated banking sector uses to settle interbank debt; ${ }^{2}$ and

2. those items, aside from bank liabilities, which are used as money.

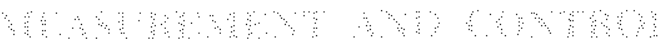

Once the monetary base is identified and measured, and the behavior of the banks and the public described and estimated, changes in the base can be used to predict changes in the money stock. What remains is the task of finding what causes the base to change and how to control these changes, since control of the size of the base, given the behavior of banks and the public, implies the control of the money stock.

If the base were to consist solely of commodity money ot real assets, then one would have to analyze the forces which affect the supply of these assets; attempts at control of these forces would constitute the exercise of monetary policy. For example, if gold coin were the sole constituent of the base, then the control of production and importation of gold coin would allow for the control of the money stock. Under

-We look at the assets of the consolidated banking sector in order to eliminate correspondent balances which are used as instrments of settement anong respondent banks. These deposits are acceptable to respondent banks only because they represent a claim on the reserves of correspondent banks, Thus, the constrant is seill exercised by the availability of assets which are not dominated by actions of individual banks. 
such circumstances, factors affecting the supply of gold coin could be identified and measured in the balance sheets of domestic gold producers and in the balance of payments.

Suppose that the base consists of currency issued by the government. If we were to assume that government maintains a complete balance sheet and that its creation of currency depends upon changes in the configuration of its assets and liabilities, then the factors affecting the monetary base would be found in and could be analyzed from the balance sheet of the government. It is usually the case, however, that govemments cannot and do not maintain complete balance sheets. Furthermore, the issuance of currency may be based on arbitrary or political decisions that cannot be quantified. Under such circtmstances the base or its currency component has to be taken as given at any time and the control of the base rests solely with governmental authorities who, in their desire to have their liabilities acceptable as money, will presumably limit currency growth.

When, in addition to the above-mentioned components, the banking system uses central bank liabilities as reserves necessary for conversion of their own monetary liabilities, the factors affecting changes in this component of the base are summarized in the balance sheet of the central bank. Central banks do maintain balance sheets and any changes in their "reserve liabilities" reflect changes in their assets and/ or other liabilities. By definition, a balance sheet implies that any subset of liabilities must equal the algebraic sum of all assets and remaining liabilities and capital in that balance sheet. Thus the central bank component of the base can be alternatively measured as the algebraic sum of all entries in the central bank balance sheet other than its reserve liabilities. This measure is frequently referred to as the "sources of the monetary base." Since factors supplying the central bank component of the base are represented in the sources, the analysis, prediction, and control of the monetary base must begin with the identification and measurement of its sources.

At present, in virtually all modern monetary systems the base consists of either central bank liabilities, government liabilities, or both. These items are the ones ased to settle interbank debt and some circulate as money. Govermment liabilities must be taken as given since decisions as to their supply are determined by factors which cannot be quantified. In the case of central bank liabilities, it is necessary to derive the sources of the base component, which consist of the algebraic sum of all other assets and liabilities in the central bank balance sheet. These sources permit the identification of causes of changes in the monetary base and, consequently, of policy actions which control these changes.

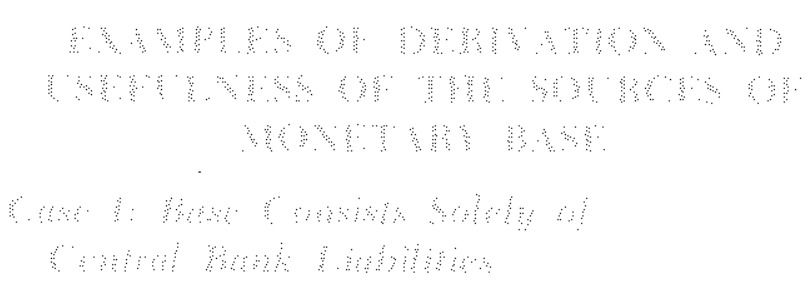

Suppose there exists a monetary system where the money stock consists of the public's deposits at banks and currency issued by the central bank and held by the public. Suppose that we observe further that the asset of the consolidated banking sector which is used to settle interbank debts consists of deposits at the central bank. Conversion of monetary liabilities of banks to the public is in the form of currency. This implies that the monetary base consists of banks' deposits at the central bank and currency issued by the central bank, which is thus the sole producer of the base. Since all changes in the base result in corresponding changes in all other entries of the central bank balance sheet, the sources of the base can be identified.

A hypothetical balance sheet of the central bank is given below.

\begin{tabular}{|c|c|}
\hline \multicolumn{2}{|c|}{ Central Bank } \\
\hline Assets & Liobillities \\
\hline Gold $(G)$ & Demand Deposits of \\
\hline Foreign Assels (FA) & Banks (DB) \\
\hline Government Securities (BC) & Currency held by Banks (CB) \\
\hline Loons and Discounts (LD) & Currency held by Public (CP) \\
\hline Other Assets (OA) & $\begin{array}{l}\text { Demand Deposits of } \\
\text { Treasury (DT) }\end{array}$ \\
\hline & $\begin{array}{l}\text { Demand Deposits of Foreign } \\
\text { Cenfral Banks (DF) }\end{array}$ \\
\hline & Currency held by Treasury (CT) \\
\hline & $\begin{array}{l}\text { Other Liabilities \& } \\
\text { Copital (OL) }\end{array}$ \\
\hline
\end{tabular}

The monetary base is comprised of demand deposits of banks at the central bank (DB) and currency, issued by the central bank, that is held by banks (CB) and by the public (CP). Thus the sources of the base, as derived from the central bank's balance sheet, are the algebraic sum of all other balance sheet entries:

$$
\mathrm{G}+\mathrm{FA}+\mathrm{BC}+\mathrm{LD}+\mathrm{OA}-\mathrm{OL}-\mathrm{DT}-\mathrm{DF}-\mathrm{CT}
$$

Measures of these items are readily available from central bank accounts and can be used to trace the 
impact of any transaction in the economy on the monetary base.

The process is simple - one must merely ascertain whether a transaction affects any of the items in the sources of the base and sum the effects. Suppose that the Treasury collects taxes and deposits the proceeds in its account at the central bank. The transactions involved are:
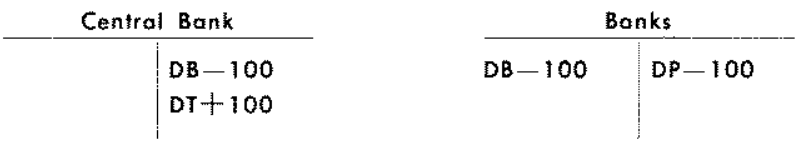

The only entry that appears in the sources statement of the base and is affected is demand deposits of the Treastuty (DT), which is a negative item and rises by 100 . Thus, the base declines by 100 . It is immediately apparent what has happened with the base and what has caused the change.

Another example could be a central bank pur. chase of Govermment securities from banks (BB).

\begin{tabular}{|c|c|}
\hline \multicolumn{2}{|c|}{ Central Bank } \\
\hline$B C+100$ & $D B+100$ \\
\hline
\end{tabular}

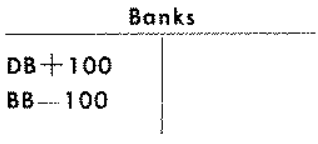

Again, the only entry affected in the sources statement is Government securities held by the central bank, an item which affects the base positively. It has risen by 100; thus the base has increased by 100 .

Suppose this country engages in attempts to peg the exchange rate. A deficit in its international balance of payments will cause the central bank to enter the exchange market as a seller of foreign currencies (its holdings of these currencies are represented by the item foreign assets). A representative net transaction would be as follows:
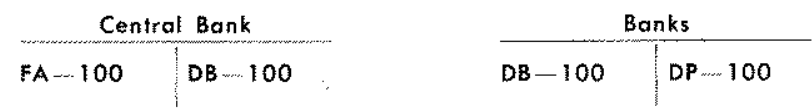

Foreign assets (FA) is the only item in the sources statement that has been affected. Its decline of 100 implies the same change in the base.

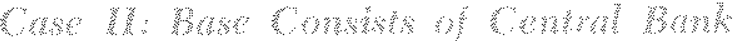

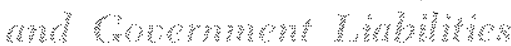

Another type of monetary system has a money stock that is made up of the public's deposits at private banks, currency issued by the govermment or by both the government and the central bank. If central bank deposit liabilities function as an instrument of interbank settlement and the public periodically converts some of its deposits into currency, the monetary base includes bank deposits at the central bank and currency issued by the central bank and by the Treasury.

In principle, this would mean that the sources statement of the base would have to be derived from the consolidation of Treasury and central bank balance sheets. But, as was discussed earlier, complete Treasury balance sheets are universally unavailable. In this case, the base and its sources must be modified by simply adding Treasury currency in the hands of banks and the public to both the base and the sources of the base. The monetary base would then become demand deposits of banks at the central bank (DB) plus central bank currency held by banks (CB) plus Treasury currency held by banks (TCB) plus central bank currency held by the public (CP) plus Treasury currency held by the public (TCP). And the sources statement is:

$$
\begin{gathered}
\mathrm{G}+\mathrm{FA}+\mathrm{BC}+\mathrm{LD}+\mathrm{OA}+\mathrm{TCB}+\mathrm{TCP} \\
-\mathrm{OL}-\mathrm{DT}-\mathrm{DF}-\mathrm{CT}
\end{gathered}
$$

The analysis uses the new statement in exactly the same way that previous transaction examples used the preceding one. Suppose that the Treasury prints and sells new currency to commercial banks and deposits the receipts in the central bank.

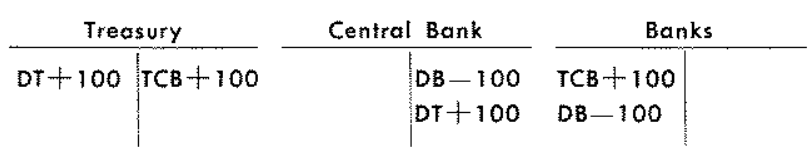

Treasury currency held by the banks increases and so do Treasury deposits at the central bank. Since they enter into the sources statement with opposite signs, there is no change in the monetary base. Commercial banks have simply changed the form of their reserves without changing the total amount.

Another illustrative transaction is the sale of Treasury currency to the central bank.

\begin{tabular}{c|ccc}
\multicolumn{2}{c}{ Treasury } & Central Bank \\
\hline DT +100 & TCC +100 & OA +100 & DT +100
\end{tabular}

Since Treasury currency at the central bank has not been specifically included in the central bank balance sheet, it must appear in other assets of the central bank (OA), which rises by 100 together with deposits of the Treasury at the central bank (DT). Since these items enter the sources statement with opposite signs there is, again, no change in the monetary base. 
But if the Treasury prints new currency and buys services from the public, the transaction is recorded as follows:

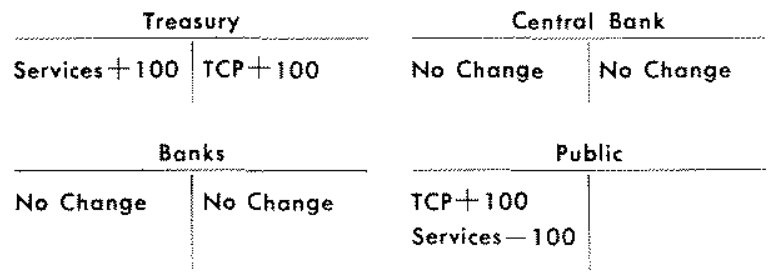

While the central bank balance sheet is unaffected, the sources statement indicates that the base rises by 100 because TCP has increased.

While the vast majority of relevant monetary systems are represented by the two cases discussed above, there are occasionally some institutional or market arrangements which require additional refine* ments.

It may be that the consolidated banking system, due perhaps to regulations imposed upon it, uses gov" ermment securities as well as central bank deposits to settle interbank liabilities. As is the case with Treasury currency, there is no government balance sheet which allows us to identify the sources of this base component; therefore, holdings of government securities by banks and the public must be added to the base and its sources as derived from the central bank balance sheet. Similarly, if any other asset is used for interbank clearing or as part of the money stock, it must be accounted for in the sources of the monetary base. The general rule for inclusion is as follows:

I. If the asset is the liability of an entity that main tains a balance sheet, the balance sheets of that entity and the central bank are to be consolidated and the sources of the base derived in a similar manner as in Case I.

II. If the asset is a liability of an entity which does not have a balance sheet, or is a real asset, then the quantities of that asset that are held by commercial banks and the public must be added to the sources and the monetary base which were constructed from the central bank balance sheet.

Obviously, analysis and control are enhanced by the ability to identify as many factors as possible that may affect monetary base. Consequently, when balance sheets are available, they should be used in the derivation of base statements. The simple addition of other assets included in the base to the sources statement assumes that these assets are predetermined and not subject to control by the central bank.

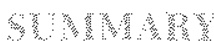

In most general terms the monetary base is that set of assets held by the banks and the public which constrains the money stock. The items that constitute the base in any comtry can be identified by determining those assets which the consolidated banking sector uses to settle interbank debt, and those items, aside from bank liabilities, which are used as money. The factors that cause the amount of base to change can be determined by consolidating the balance sheets of the producers of the base. In the case where the central bank is the sole producer of base, this process can proceed from the balance sheet of the central bank. Any change in the base will appear as a change in one or more other entries in the central bank's balance sheet. When there are other producers of base, such as the Treasury, this article showed how the base could be constructed to take this into account.

The sources statement of the base is most important to the monetary authorities. This statement serves as a scheme for analyzing how actions taken by the monetary authorities, such as purchases or sales of securities, or lending to banks, influences the base and, hence, the money stock. It also permits them to analyze how other factors influence the base and, consequently, permits them to identify the type of offsetting actions that must be taken to counter these outside influences.

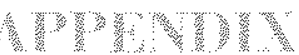

The purpose of this Appendix is to demonstrate how the principles of monetary base construction can be applied to the U. S. monetary system and to show how a base construct can be reconciled with data which is regularly published in the Federal Reserve Bulletin.
The U. S. monetary system is characterized by the existence of three sets of money-creating institutions: (1) the U. S. Treasury which issues coin and which has some Treasury notes and silver certificates outstanding, (2) the Federal Reserve System, which issues Federal 
Reserve notes and demand deposits, and (3) commercial banks which issue demand deposits. Commercial banks, which constitute the private money-creating sector, can use as instruments of settlement currency (Federal Reserve notes and Treasury curtency and coin) and demand deposits at the Federal Reserve Banks. Therefore, the base consists of monetary assets of the consolidated domestic private sector (currency and con held by banks and the public, and demand deposits of member banks at Federal Reserve Banks). These are the monetary liabilities of the Government sector to the private domestic sector. Consequently, the base and the sources of the base, as derived from the Federal Reserve balance sheet, must be supplem mented by the addition of Treasury currency and coin held by commercial banks and the public.

It should also be noted that certain monetary relation. ships between the central bank and the government are inique to U. S. monetary institutions. For example, gold is held by the Treasury, which issues gold certificates to the Federal Reserve System, and coin is issued by the Treasury while almost all of the currency is issued by the Federal Reserve Banks. These unique features, however, present no difficulty in the development of base statements and perhaps demonstrate even more forcefully that such construction is applicable to all institutional arrangements.

A simplified balance sheet for the Federal Reserve System is given below:

\section{Federal Reserve System}

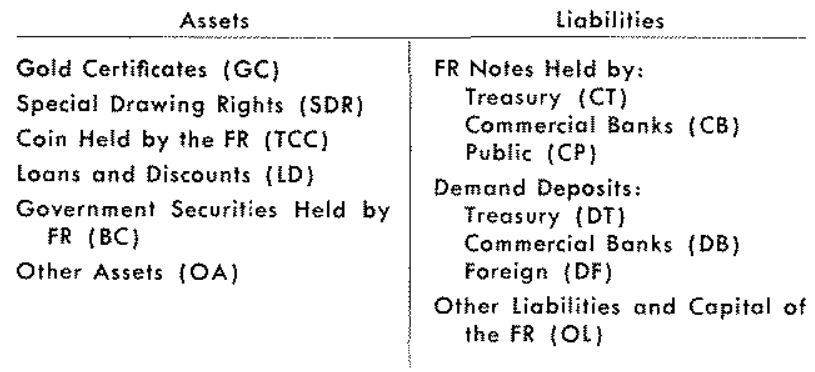

The base, as defined and identified in the Federal Reserve's balance sheet, consists of demand deposits of banks at the Federal Reserve Banks (DB), Federal Reserve Notes held by banks and the public (CB + CP) and Treasury currency held by banks (TCB) and the public (TCP):

$$
\mathrm{DB}+\mathrm{CB}+\mathrm{CP}+\mathrm{TCB}+\mathrm{TCP}
$$

The sources statement consists of the algebraic sum of all the remaining assets and liabilities in the Federal Reserve balance sheet plus monetary liablities of the Treasury held by banks and the public (TCB + TCP). Therefore, the sources of the base consist of the following balance sheet entries:

$$
\begin{gathered}
\mathrm{LD}+\mathrm{BC}+\mathrm{OA}+\mathrm{GC}+\mathrm{SDR}+\mathrm{TCC}-\mathrm{CT} \\
-\mathrm{DT}-\mathrm{DF}-\mathrm{OL}+\mathrm{TCB}+\mathrm{TCP}
\end{gathered}
$$

Data for derivation of sources of the base is published monthy in the Federal Reserve Bulletin in a table entitled "Member Bank Reserves, Reserve Bank Credit, and Related Items." This Table is divided into two parts:

\author{
Factors supplying reserve funds: \\ Reserve Bank Credit Outstanding (RBC) \\ Gold Stock (G) \\ Special Drawing Rights (SDR) \\ Treasury Currency Ontstanding (TCO), and \\ Factors absorbing reserve funds: \\ Currency in Circulation (CC) \\ Treasury Cash Holdings (TK) \\ Deposits, other than Member Bank \\ Reserves with FR (d) \\ Other Federal Reserve Liabilities \\ and Capital (OL) \\ Member Bank Reserves with FR Banks (DB) \\ Currency and Coin held by \\ Member Banks (CMB)
}

In terms of this statement, the base consists of member bank deposits at Federal Reserve banks (DB) plus currency and coin in circulation issued by the Federal Reserve Banks ( $C B+C P$ ) and issued by the Treasury (TCB + TCP). Thus, in terms of our balance sheet notation, it consists of $\mathrm{DB}+\mathrm{CB}+\mathrm{CP}+\mathrm{TCB}+\mathrm{TCP}$ which is identical to statement (1) from the balance sheet of the Federal Reserve.

For the sources statement we have to define the published entities in terms of balance sheet notation.

$$
\begin{aligned}
\mathrm{RBC}= & \mathrm{LD}+\mathrm{BC}+\mathrm{OA} \text { (where Federal Reserve toat } \\
& \text { is included in OA) } \\
\mathrm{G}= & \text { Gold } \\
\mathrm{SDR}= & \text { Special Drawing Rights } \\
\mathrm{TCO}= & \mathrm{TCB}+\mathrm{TCP}+\mathrm{TCC}+\mathrm{TCT} \text { (where TCT re- } \\
& \text { fers to Treasury currency held by the Treasury) } \\
\mathrm{TK}= & (\mathrm{G}+\mathrm{GC})+\mathrm{TCT}+\mathrm{CT} \\
\mathrm{d}= & \mathrm{DT}+\mathrm{DF} \\
\mathrm{OL}= & \text { Other Liabilities }
\end{aligned}
$$

The soumes statement, which is derivable from factors supplying and absorbing reserve funds, is:

$$
\mathrm{RBC}+\mathrm{G}+\mathrm{SDR}+\mathrm{TCO} \ldots \mathrm{TK}-\mathrm{d}-\mathrm{OL} \text {. }
$$

When balance sheet notation is substituted for published notation, and addition and subtraction are completed, statement (3) becomes,

$$
\begin{gathered}
\mathrm{LD}+\mathrm{BC}+\mathrm{OA}+\mathrm{CC}+\mathrm{SDR}+\mathrm{TCC}-\mathrm{CT} \\
-\mathrm{DT}-\mathrm{DF}-\mathrm{OL}+\mathrm{TCB}+\mathrm{TCP}
\end{gathered}
$$

This statement is an identical statement to (2) which implies that the data published in the form of factors supplying and absorbing reserve funds is consistent with the sources statement as derived from the Federal Reserve balance sheet.

As an example of this procedure the following numerical example is presented. The balance sheet for the Federal Reserve System is for September 29, 1976, as reported on page $A 10$ of the October 1976 Federal Reserve Bulletin.

IFederal Reserve float is computed from the balance sheets and is cash items in process of collection minus deferred availability cash items. See Federal Reserve Bank of New York, Glossary: Weehly Federal Reserve Statements, "Factors Affecting Bank Reserves" (October 1975), pp. 17-18. 


\begin{tabular}{|c|c|c|c|}
\hline \multicolumn{4}{|c|}{$\begin{array}{l}\text { Consolidated Statement of Conditi } \\
\text { All Federal Reserve Banks } \\
\text { (millions of dotlars) }\end{array}$} \\
\hline \multicolumn{2}{|l|}{ Assets } & \multicolumn{2}{|l|}{ Liabilities } \\
\hline Gold Cerlificates & $\$ 11,598$ & FR Noies & $\$ 79,802$ \\
\hline SDR & 700 & Demand Deposits: & \\
\hline Costs Held by FR & 365 & Trecisury & 12,212 \\
\hline Loons and Discounts & 324 & $\begin{array}{l}\text { Member Bank } \\
\text { Reserves }\end{array}$ & 29,807 \\
\hline $\begin{array}{l}\text { Government Securities } \\
\text { Held by FR }\end{array}$ & 99,224 & Foreign & 245 \\
\hline Other Assets & 19,694 & and Capital & 9,839 \\
\hline & $\$ 131,905$ & & $\$ 131.905$ \\
\hline
\end{tabular}

In the notation used in this appendix, the base consists of demand deposits of commercial banks held at Federal Reserve Banks (DB) which equal $\$ 29,807$ plus currency held by commercial banks and the public $(\mathrm{CP}+\mathrm{CB}+\mathrm{TCP}+\mathrm{TCB})$. This currency consists of $\mathrm{FR}$ notes $(\$ 79,802)$ plus Treasury currency outstanding $(\$ 10,757)$ which comes from the Treasury accounts, less the currency and coin held by Treasury $(\$ 425)$, called "Treasury cash," less Federal Reserve holdings of coin, called "cash held by FR" (\$365). The total currency component of the base consists of $\$ 89,769$ million. Therefore, the base amounts to $\$ 29,807$ plus $\$ 89,769$ and equals $\$ 1,19,576$.

The sources of the base consist of Treasury currency and coin held by commercial banks and the public, and all the items in the Federal Reserve's balance sheet except the two entries demand deposits of commercial banks (member bank reserves) and Federal Reserve notes. In other words, if one consolidates all the entries in the Federal Reserve balance sheet for the week of September 29 ,

Inckudes $\$ 920$ million of other deposits.

FR notes held by FR banks are excluded from the entry. "FR notes" in the consolidated balance sheet.
1976, excluding Federal Reserve notes $(\$ 79,802)$ and demand deposits of member banks $(\$ 29,807)$, the total amount is $\$ 109,609$ million. As was shown previously the amount of Treasury currency and coin held by commercial banks and the public was $\$ 9,967$ million for the same date. Hence, the total base is $\$ 109,609$ plus $\$ 9,967$ equals $\$ 119,576$ million.

Using the notation presented in this appendix, the sources of the base may also be constructed from the entries that appear in the table "Member Bank Reserves, Federal Reserve Bank Credit, and Related Items" that appears on pages A2 - A3 of the October 1976 Federal Reserve Bulletin. For September 29, 1976, the data are as follows:

Reserve Bank Credit (RBC) …......\$113,972 million

$\begin{array}{lr}\text { Gold (G) } & 11,598 \\ \text { SDR . } & 700 \\ \text { Treasury Currency } & 10,757 \\ \text { Outstanding (TCO) } & 425 \\ \text { Treasury Cash (TK) } & \\ \text { Demand Deposits of } & 12,212 \\ \quad \text { Treasury (DT) } & 245 \\ \text { Foreign Demand Deposits (DF) } & 4,569 \\ \text { Other Liabilities (OL) }\end{array}$

Using the previous formula for the sources of the base given in equation (3):

$\mathrm{RBC}+\mathrm{G}+\mathrm{SDRs}+\mathrm{TCO}-\mathrm{TK}-\mathrm{DT}-\mathrm{DF}-\mathrm{OL}$

we find that the summation of the sources stated in this manner, and applying the appropriate sign, equals $\$ 119,576$ which is exactly equal to the base as derived from the Federal Reserve's balance sheet with the addition of Treasury currency held by commercial banks and the public.

4Treasury currency and coin held by banks and the public is the sum of silver certificates, United States notes and total coin. These amounts are available for the end of the month in Table MS.I, "Currency and Coin in Circulation," U. $S$, Department of the Treasury, Treasury Bulletin.

Includes $\$ 920$ million of other deposits. 